\title{
NEOCOLONIAL SUBTEXT IN WESTERN MEDIA COVERAGE OF UKRAINIAN CRISIS Iryna Lazurkevych ${ }^{7}$
}

\begin{abstract}
The article examines one of the key factors of modern European philosophy and outlook neocolonialistic and orientalistic mentality of nowadays Europe and its impact on the informatioanal sphere and the character of inernational relations.

Neocolonialism and orientalism are, thus, studied in the context of the analysis of western media coverage of Ukrainian crisis which occasionaly appears to be stereotyped and deeply engaged.
\end{abstract}

Keywords: neocolonialism, new orientalism, spheres of influence, Ukrainian crisis, media coverage.

\section{Introduction}

Ukrainian "Dignity Revolution" and the subsequent war, more commonly known as Ukrainian crisis, currently is being widely discussed among the international community. What counts here is that the starting point of the ray of these eventswasUkrainian public movement in defence of "european values". Intrinsically Europe in its turn was expected to be unanimous and consential on this issue. But western media coverage of Ukrainiancrisis, however, isn't homogeneous.

On the one hand, we are witnesses of Europe's declaring support and solidarity, though often along with their formal "deep anxiety and concern", whereas on the others, such newspapers as The Guardian, for instance, where "comments are free", contain abundunt prejudices and stereotypes concerning Ukraine and portray it based on some neo-colonial and pro-russian thinking, operating with categories, which could be interpreted as a display of so called "latent neocolonialism and orientalism".

Thus, the goal of the article is the analysis of colonial and imperialistic roots of the phenomenon of russian-engaged publications in European press, as well as the examination of the role of colonial Europe's historyin the formation of nowadays neocolonial approach in European media concerning various sociopolitical processes in the postcolonial modern world.

While speaking about this problem it is vital to note few points concerning the subject of our research.

First of all, it is indisputable that the emergence of pro-russian comments and publications in European press couldn't be treated as a prevailing tendency. They are 
more likely to be single exceptions or, better say, implicit meanings of the articles, which nevertheless regularly appear in western press, taking their part in the creation of Ukraine's international image and thereforedeserving scrutiny as well.

Secondly, such a stereotyped coverage emerges in the aggregate of different conditions and thereforeneocolonialism is not the single one, nor the most crucial factor. Many other filosophical and sociopolitical explanations could be supplied. Thus, this article doesn't set the aim to depict neo-colonial thinking as the root cause of such coverage but to figure it out as, definitely, one of the most significant factors which defines the character of media issues, and to emhasize on its role in the formation of european world-outlook.

\section{Fundamental principles of neocolonial worldview}

Current political and economical circumstances, as well as history of particular nation, create a specific ideological sphere which defines the character of media coverage, as well as certain "riddle" of persuations and stereotypes through wich the world is "sifted".

This principle also concerns geopolitics. Giambattista Vico - the founder of modern philosophy of history - claimed that "people create their history, they are able

to comprehend solely the things they have created themselves and they have extended that knowledge to geography as well" [Саїд, 2001, p. 16].

In other words, the history of imperialism became such ideological "riddle" for contemporary Europeans who sometimes unconsciously percieve the world through the categories of postcolonialism. In due time John Stuart Mill, Thomas Carlyle, Thomas Babington Macaulay, George Eliot, Charles Dickens - all they also had "well-defined visions of race and imperialism, which could have been easily noticed in their writings" [Саїд, 2001, p. 27]. Therefore, small wonder that current neocolonial inclinations of Europe are to be found in nowadays journalists' articles.

Concerning imperialism, colonialism and neocolonialism it is important to note that, nowadays, they could be seen in two ways: as the explicit historical phenomena and as the implicit mental patterns which could be noticed in modern European culture, journalism etc.

Encyclopedia Britannica provides a definition: "The term neocolonialism was originally applied to European policies that were seen as schemes to maintain control of African and other dependencies.... [It]came to be seen more generally as involving a coordinated effort by former colonial powers and other developed countries to block growth in developing countries and retain them as sources of cheap raw materials and cheap labour" [Halperin].

Neocolonialism has been studied so far by Naom Chomsky, Jean-Paul Sartre, David Harvey. But the term was firstly coined after the Second World War by Kwame Nkrumah, the president of Ghana. According to Nkrumah, neocolonial exploitation "operates not 
only in the economic field, but also in the political, religious, ideological and cultural spheres" [Nkrumah, 1965]. That's why it matters in the context of Ukrainian question.

Modern neocolonialism while looking at the geopolitics, takes into account several basic statements:

\section{Spheres of influence.}

Postcolonial world is modeled after the scheme ofmonopolies and colonies with the only difference that colonies are substituted now with spheres of influence and monopolies - with high-developed and prosperous countries which became now investors to the first. "After World War I imperialism was expiring but the spheres of influence came instead» [Фішер, 2013, p. 138].

The researcher of Ameriacan economical neocolonialism David Harvey in his study "New Imperialism" noticed: "...each developing centre of capital accumulation sought out systematic spatio-temporal fixes for its own surplus capital by defining territorial spheres of influence" [Harvey, 2003, p.185]. Thus, Ukraine today is occasionally elucidated as the sphere or Russian's influence.

\section{Centre-periphery system.}

The postcolonial world is conditionally divided into centres and peripheries. This division appeals to so called "dependency theory", which is the theoretic basis of economic neocolonialism and provides that the global economic system comprises wealthy countries at the center, and poor countries of developing economic - at the periphery.

\section{Military intervention - as a modern form of new colonialism.}

Colonial system of the past implied that not only the political power but also cultural values and state system were extended to colonies. It was a kind of "soft-intervention" or "soft-interference". Nowadays, the analogue of such colonial interference, according to David Harvey [2003], is a straightforward military intervention of US, for instance, disguised as the humanitarian aid.

These basic neocolonial mental patterns may prove helpful in understanding the pro-russian engagement of some western journalists' materials.

\section{Ukrainian crisis through the categories of neocolonial mentality: media aspect.}

Since November 2013 Ukraine has been fallen victim to the wave of Russian media distortion and propaganda, what appears to be unsurprisingly. But what strikes the most, is that the certain part of western media coverage, even though implicitly, is akin to the russian one.

Thus, let's examine the most frequent distortions in western media coverage in the light of previously indicated parameters of neocolonial ideology.

Profoundly respected in Europe The Guardian has published an article under the heading "Finland Warns of New Cold War over Failure to Grasp Situation in Russia", in 
whichFinnish president Sauli Niinisto was quated: "Western countries are at the gates of a new cold war with Russia sparked by the Ukraine crisis and a continuing failure to grasp the depth and seriousness of Vladimir Putin's grievances with the US and EU" [Tisdall, 2014]. This statement resonates, for example, with the similar approach of Peter Hitchens, expressed in his blog on Daily Mail's Online [Hitchens, 2014].

The point is, that Ukrainian revolution and Ukrainian-Russian war are depicted in these articles in terms of political pretext or so called "spark" which can inflame the "real conflict", which supposed to be Cold War II, whreas Ukrainian events themselves,therefore, obtain no ponderable value. This misconception could be simply explained in terms of neocolonial biased outlook which admits exclusively the bipolar world and the exceptioanal right of former empires, but not the nation states, to play a vital role in the XXI centuary.It is the colonial perception of the subject of international relations. Ukraine has never been considered to be a subject so far.

Providing that, Ukraine in such interpretation can't bid for the status offully-fledged player.This is the essence of the second category of articles, that with a grudge against West affirm that Ukrainian revolution has been ispired and "bribed" by West (read - US), since Ukraine itself is not capable of being a driving force of such a large-scaled events.

For instance, journalist John Pilger in his article written for The Guardian "In Ukraine, the US is dragging us towards war with Russia" blames US for the incitement of Ukrainian revolution. "For the first time since the Reagan years, the US is threatening to take the world to war, - he claimes. - Why do we tolerate the threat of another world war in our name? Why do we allow lies that justify this risk?" [Pilger, 2014].

What's paradoxical, though alleged and imaginary,anywestern interferance is strongly condemned, since it is considered to be an echo of Europe's colonial history. But Europe, castigating itself for its colonial past, now denies any single fact of interference (even though while sometimes carring on interferring indirectly) and declare tolerance and impartiality. And the fact that Ukrainians defended "european values" induces Europe to renounce being involved in it. It resembles a phenomenon of postcolonial "contrition" - feeling remorse for so called "imperialistic sin" as an attempt to impose European values.

These approach appeals to the neocolonial percepcion of the world as the place, where power, ideas, capital and cultural values could circulate exceptionally in one direction: from the developed countries or former monopolies and to the developing ones. But at the same time, it implies two aspects: on the one hand, it is hardly belived that "former Russian colony" could be an initiator of significant processes, and on the others -any hint on direct western interference is objectionable.

Fabio Belafatti, Italian journalist, once has neatly commented on this question: "Unsurprisingly, pro-Russian commentators almost never speak in terms of "access of Eastern Europe into NATO," but of "NATO/EU expansion in Eastern Europe." The "East" is seen as a land of conquest - by nature subordinated to Russia - in which "the West" engages in dangerous games against its "legitimate" owner" [Belafatti, 2014]. 
in media: "Prejudice is rife. For example, wherever there is armed struggle against the forces of reaction, the nationalists are referred to as rebels, terrorists, or frequently 'communist terrorists'!" [Nkrumah, 1965].

Thus, already mentioned John Pilger in his article says: "Washington's role in Ukraine, and its backing for the regime's neo-Nazis, has huge implications for the rest of the world" [Pilger, 2014]. And the Global Research portal submits the article "Ukraine and the Rebirth of Fascism in Europe", where the Revolution of Dignity is contempted by the words: "The violence on the streets of Ukraine is far more than an expression of popular anger against a government. ... It is merely the latest example of the rise of the most insidious form of fascism" [Draitser, 2014]. These examples show how the simplified ideological templates of new orientalistic approach work in media coverage.

But there is a back side of such coverage. George Soros, a Hungarian-born American business magnate, investor, and a chairman of Soros Fund Management, at the first glance, takes an unambiguous position concerning Ukraine in his article "Wake Up, Europe" [Soros, 2014]. Ukraine is depicted in a slightly pathetic way as a "cradle" of democratic values. "New Ukraine", hidden strenght of the nation - could there ever be more pro-ukrainian approach?"People have proven their willingness to sacrifice their lives for their country. These are the hidden strenght of the new Ukrain" - Soros writes.

But under the guise of this eloquent rhetoric a latent orientalism is revealed. The explicit fact that Ukraine is also a large-scaled financial market for Europe couldn't be underestimated. Thus, it is also an attempt to take care of the "weak" East, which itself could be interpreted as paternalistic European approach of new orientalism.

"The collapse of Ukraine would be a tremenduous loss for NATO, the European Union, and the Unighted States", - claims Soros apealing to the spiritual value of Ukraine, whereas making unambiguous calculations of the most benefitialfinancial loans given by Europe to Ukraine. "The European Union would save itself by saving Ukraine" - he concluded. Thus, beside "genuine" pro-ukrainian rhetoric, the pragmatic approach considering Ukraine to be an object, a sphere of influence and a sales market is easily seen.

\section{Conclusion}

Summing it up, it is essential to realize that colonial past of Europe is today like a historical "cargo" it has to bear. And it ultimately defines Europeans' outlook.

We can denote the most frequent misconceptions in western media coverage concerning Ukrainian crisis, that could be interpreted as a letant forms of neocolonialism and new orientalism:

1. Ukraine is hardly believed to be a subject of the international relations or an independent "player",taking into consideration that it has never been an empire or monopoly before.

2. It is rather believed to be an "unannounced" sphere of influence of theformer 
empire - Russian Federation - or at least a "periphery", but not the "centre".

3. According to new orientalistic stereotyped approach, all Ukrainianrevolutionary movements are posessed as those striving for creation of the artificial natioanl identity or for reanimation of extremist regime, and Ukraine itself - as a disabled country requiring Europe's care.

But the main point is that these misconceptions prevail no more today and are doomed to dethronement and debunking by current events.

On the whole, these events appears to be the chance for Ukraine to rid itself of the disparaging and humiliating status of "former Russian colony" or current Russian sphere of influence, to establish itself as a subject and to break the neo-colonial and oriental stereotypes regarding the world order and nation states, in particular.

\section{References}

Конквест, Р. (2003). Роздуми над сплюндрованим сторіччям. Київ: Видавництво Соломії Павличко «Основи".

Саїд, Е. (2001). Орієнталізм.Київ: Видавництво Соломії Павличко «Основи».

Фішер, Й. (2013). Історія повертається:світ після 11 вересня і відродження Заходу. Київ: Темпора.

BELAFATII, F. (2014, October, 27). Orientalism reanimated: colonial thinking in Western analysts' comments on Ukraine [web-resource]. Massage posted to http://euromaidanpress.com/2014/10/27/westerncommentators-should-rid-themselves-of-old-prejudices-dating-back-from-the-age-of-colonialism-beforecommenting-on-eastern-european-affairs/

DRAITSER, E. (2014, February, 20). Ukraine and the Rebirth of Fascism in Europe [web-resource]. Massage posted to http://www.globalresearch.ca/ukraine-and-the-rebirth-of-fascism-in-europe/5366852

HALPERIN, S. (2014, January, 2014) Neocolonialism [Encyclopedia Britannica.] Massage posted to http:// www.britannica.com/EBchecked/topic/408815/neocolonialism

HARVEY, D. (2003). The New Imperialism. Oxford. : Oxford University Press.

HITCHENS, P. (2014, April, 23). Still not Getting the Point on Ukraine [blog]. Massage posted to http:// hitchensblog.mailonsunday.co.uk/2014/04/still-not-getting-the-point-on-ukraine.html

NKRUMAH, K. (1965). Neo-Colonialism, The Last Stage of Imperialism. [web-resource]. Massaage posted to http://sfr-21.org/neocolonialism.html

PILGER, J. (2014, May, 13). In Ukraine, the US is dragging us towards war with Russia [online-media]. Massage posted to http://www.theguardian.com/commentisfree/2014/may/13/ukraine-us-war-russia-john-pilger

SOROS, G. (2014, November, 20). Wake Up, Europe. [online-media]. Massage posted to http://www.nybooks. com/articles/archives/2014/nov/20/wake-up-europe/

TISDALL, S. (2014, November, 5). Finland warns of new cold war over failure to grasp situation in Russia. [onlie-media]. Massage posted to http://www.theguardian.com/world/2014/nov/05/finland-warns-cold-warrussia-eu 